\title{
Legal Policy of Interfaith Marriage in Indonesia
}

\author{
Fathol Hedi' ${ }^{1}$ Abdul Ghofur Anshori², Harun ${ }^{3}$ \\ ${ }^{1}$ Faculty of Syari'ah, Institut Islam Mamba'ul 'Ulum Surakarta, Indonesia. E-mail: fatholhedi71@gmail.com \\ 2 Faculty of Law, Gadjah Mada University, Indonesia. E-mail: anshori@mail.ugm.ac.id \\ ${ }^{3}$ Faculty of Law, Muhammadiyah University of Surakarta, Indonesia. E-mail: harun@ums.ac.id
}

\section{ARTICLE INFO}

Keywords:

Interfaith Marriage; Islamic Law; Legal Policy; Marriage Law

How to cite:

Hedi, F., Anshori, A.G., E Harun. (2017). Legal Policy of Interfaith Marriage in Indonesia. Hasanuddin Law Review, 3(3): 263-276

DOI:

10.20956/halrev.v3i3.1297

\begin{abstract}
Marriage is not just a bond between men and women, but the inner bond between a man and a woman based on the One and Only God. This research was a philosophical normative, thus the approaches used were philosophical, normative, and historical. Besides, a qualitativedescriptive strategy was used in finding a depth description of the law politics of interfaith marriage regulation in Indonesia based on the the 1974 Marriage Law. The results show that the interfaith marriage is not regulated in the 1974 Marriage Law, because: First, the rejection of the majority of Muslims and the faction in Parliament because the interfaith marriage is against the aqidah (matters of faith) of Islam; Second, the interfaith marriage is contrary to the marriage culture in Indonesia, because marriage contains legal, sociology and religious aspects; Third, the interfaith marriage is contrary to the theological teachings of religions in Indonesia that do not want interfaith marriages, such as Islam, Christianity, Protestantism, Hinduism and Buddhism. Furthermore, the interfaith marriage is inconsistent with the philosophical purposes of marriage in Indonesia where the purpose of marriage forms a happy and eternal family based on the One Supreme God.
\end{abstract}

Copyright $\odot 2017$ HALREV. All rights reserved.

\section{Introduction}

In principle, marriage is the law of God (sunnatullah). Hence, marriage is not a bond between men and women only, but the bond is also full of values of human nature. ${ }^{1}$ Marriage has a very important part in human life, because with the existence of marriage, the intercommunication between men and women entrenched honorably

1 Article 1 Law No. 1 of 1974 on Marriage (The 1974 Marriage Law) mentioned: "Marriage is the inner bond between a man and a woman as husband and wife with the aim of forming a happy and eternal family (household) based on the One and Only God." While in the Compilation of Islamic Law (KHI) Article 2 mentioned: "Marriage is a very strong contract (miitsaqan ghalidhan) to adhere Allah command and perform it is as a worship." 
according to human position as a noble creature of God. ${ }^{2}$ Every religion upholds marriage recognizes its sanctity and governs the institution of marriage. ${ }^{3}$

In this regards, although Indonesia now has the biggest Muslim population in the world (about 225 million of the nation's 259 million people are Muslim), there are millions of followers of other religions, such as Christianity, Hinduism, Buddhism, and Confucianism. These minority groups must be embraced by the nation - that was the aim of the founding parents. With the motto "Bhinneka Tunggal Ika" (Unity in Diversity), Indonesia's proclaimers of independence decided the archipelago would be unified as the Unitary State of the Republic of Indonesia. ${ }^{4}$ This was followed on 1 June 1945 by the announcement of the state ideology "Pancasila", the first principle of which is 'Belief in the one and only God'. 5

In Indonesia, the plurality of cultures, tribes, and religions have colored the marriage style in society, for example the interfaith marriage. ${ }^{6}$ Interfaith marriage often causes complicated matters for individuals, families, society and even country. Interfaith marriage often gets rejection from family, even from the authorized institution which manage marriage registry. For example, the marriage case of Nia Zulkarnain (Islam) with Ari Sihasale (Catholic), Jamal Mirdad (Islam) with Lydia Kandauw (Kristen), Yuni Shara (Islam) with Henry Siahaan (Catholic), and others. In obtaining the formal legal status from the state, they are engaged in marriage by doing subordination to one of their partner's religion, religious conversion, court settlement and even marriage abroad. ${ }^{7}$

Normatively, in a positive law context, the legal certainty of interfaith marriage is still disputed, because the Law No. 1 of 1974 on Marriage (The 1974 Marriage Law) is not clearly and explicitly regulated it. Article 57 of the 1974 Marriage Law only regulates the mixed marriages. ${ }^{8}$ The meaning of intermarriage in the 1974 Marriage is narrower than what is meant by GHR (Regeling op de Gemengde Huwelijken) in which the Article 1 states: "Intermarriage is a marriage between Indonesian people who abide on different laws." Intermarriage is not only about the differences of citizenship, but it also includes marriage of different religions, marriage of different groups, even marriage of different customs.

2 In Q.S Al-Israa': 70 "And We have certainly honored the children of Adam and carried them on the land and sea and provided for them of the good things and preferred them over much of what We have created, with (definite) preference." Department of Religious Affair RI, Al-Qur'an and its Translation, Thoha Putra: Semarang, p. 435.

3 Arief, A.S. (2003). Pembaharuan Pemikiran Hukum Islam: Antara Fakta dan Realita (Kajian Pemikiran Hukum Syaikh Muhammad Syaltut). Yogyakarta: LESFI, p. 120.

4 Bhinneka Tunggal Ika, the national motto, literally means "in pieces, yet one" and is officially translated as "Unity in Diversity".

5 Susanto, E. H., \& Zhang, S. D. (2017). Critical Discourse Analysis of Interfaith Marriage News from Cyber Media in Indonesia. Journal of Educational and Social Research, 7(1), 91.

6 While the interfaith marriage in The 1974 Marriage Law is not regulated. Interfaith marriage does not belong to Intermarriage, as what is in Article 57, and explained further on Article 58 until Article 62.

7 In society, there are some types of interfaith marriage: first, one of the parties switch his or her religion. Second, one of the parties resigns or converts formally to the religious law of the husband or the wife. Third, the marriage is only held in Registry Office. This marriage should get stipulation from the court. This stipulation, in line with the explanation of Article 35 letter (a) of Law No. 23 of 2006 on the Population Administration. Fourth, interfaith marriage is done abroad.

8 Further explanation about the interfaith marriage which is meant in the 1974 Marriage Law, it is explained in the Article 58 to Article 62. 
As there is no explicit accommodation of interfaith marriage in the 1974 Marriage Law, it raises various interpretations among jurists. Referring to Article 66 of the 1974 Marriage Law, interfaith marriage may be held, because the article indicates the enforcement of the previous regulation. The Marriage Law does not contain any provision stating that the religious difference between a prospective married couple is a prohibition on a marriage. Only in the 1974 Marriage Law of Article 2 paragraph (1) states, "Marriage is lawful if it is done according to the law of their respective religion and belief." Philosophically, the 1974 Marriage Law, GHR of 1898 and BW (Burgerlijk Wetboek) have a fundamental difference, which is in the 1974 Marriage Law considers the validity of marriage based on religion, while GHR and BW consider the validity of marriage only in terms of civility.

Nowadays, the tendency of interfaith marriage in Indonesia increases due to the plurality of society of which ethnic, tribe, culture and religion are diverse. Pancasila as the foundation of legal norms gives equal protection to all citizens according to its fifth principle: "Social justice for all Indonesian people." The legal norm is strengthened with the Article 27 of the 1945 Constitution concerning the equality before the law. Article 29 of the 1945 Constitution gives freedom to citizens to have their respective religions and beliefs. This is further strengthened by Law No. 39 of 1999 on Human Rights.

The unclear legislation concerning the arrangement of interfaith marriage in Indonesia has affected the interpretation of legal provisions, therefore in practice of the courts there is often a dualism of decisions. On one side, the Court allows the execution of interfaith marriages on certain conditions, but on the other side, the court in the certain areas prohibits it for different reasons. According to Pancasila and the 1945 Constitution, the state as an institution has given equal protection and opportunity for every citizen in the legal regulation in which stated in Preamble of the 1945 Constitution.

The realization of social justice for all Indonesian people, necessitate the enactment of the law and its regulation is applied equally to every citizen without discrimination. The enactment of regulations without discrimination not only views the implementer of the regulation side, but it also has to examine the essence of regulatory content from various perspectives whether it is philosophically, normatively, or sociologically, especially on marriage. The release the 1974 Marriage Law is a form of legal unification of a variety of previous marriage rules. According to Anshori, ${ }^{9}$ he stated that:

Unification form of the 1974 Marriage Law embraces the concept of deferential unification, meaning that on one side of the marriage rule in Indonesia abolishes legal pluralism, but on the other side of the law still accommodates the differences of religious law which are applied to each of its adherents, as stated in Article 2: (1) marriage is lawful if it is done according to his religious law and belief; (2) Each marriage shall be registered in accordance with applicable laws and regulations.

The unification of marriage regulation into a single law for all citizens was initially opposed by Muslims, sociological organizations and a debate in the legislature. Many articles in the Bill of marriage are considered as incompatible with Islamic marriage and defiant from Pancasila as the nation's ideology. It is also similar with the suitability of interfaith marriage purpose with philosophy values of marriage purposes in

9 Anshori, A.G. (2012), Antologi Hukum Islam. Program Studi Hukum Islam Program Pascasarjana Universitas Islam Negeri Sunan Kalijaga: Yogyakarta, p. 26. 
Indonesia. This becomes urgently reference in determining the political ius constituendum of interfaith marriage law.

The expected contributions of this dissertation are: first, able to contribute the thinking of science development in the field of law and in order to improve the founding as well as finding of the political dimension of the law of interfaith marriage Law no. 1 of 1974, the synchronization of interfaith marriage with the philosophy values of marriage purpose in the Pancasila state and the following ius constituendum of marriage law politics. Second, it provides a clear picture of the legal political dimension in interfaith marriage law dispute in Indonesia, furthermore as a referential study material and consideration in the preparation of legislation for the competent parties, especially on marriage legislation in Indonesia. This research was a philosophical normative, thus the approaches used were philosophical, normative, and historical. Besides, a qualitative-descriptive strategy was used in finding a depth description of the law politics of interfaith marriage regulation in Indonesia based on the the 1974 Marriage Law. 10

\section{The History of Interfaith Marriage in Indonesian Law}

Islam was brought to Indonesia in the 13th century by Muslim traders and by the 16th century it had become the dominant religion in Java and Sumatra islands, surpassing Hinduism and Buddhism. One of the ways Islam spread in Nusantara (the Indonesian archipelago) was through marriage. ${ }^{11}$ Efforts to promote Islamic law in Indonesia as a law of which the existence is acknowledged as material law are once applied and developed within the Islamic society. ${ }^{12}$ Especially those which are regarded as family law which has been running in Indonesia for centuries, though not yet codified until colonialism era. ${ }^{13}$

Since establishing the Vereenigde Oost Indische Compagnie (VOC) in East India, Netherland applied family law in the form of the Resolutie der Indische Regeering regulation 1760 or Compendium Freijer (a set of Islamic law of marriage and inheritance), and it is regarded as the first Islamic law in the VOC era. ${ }^{14}$ By the enactment of Cempendium Freijer by the VOC, then at the same time, it is also used as the basis of law of Religious Courts (PA). This is reflected in Article 134 clause 2 of the Indische Staatsregeling that civil cases arising among the Moslem are judged by the Religious Courts, if their customary law finds them, unless by some other Law which is stipulated..$^{15}$ It is only that based on Ind. Stbl No. 55, on the third of August, 1828, the partially renewed Compendium Freijer was later gradually revoked in the nineteenth century. For the last part, which is about the inheritance, it is only revoked on the seventeenth of February, 1913 with Stbl. No. 354. In the Dutch period, marriage was regulated in several regulation according to its class. ${ }^{16}$

10 Bable, E. (2002). The Basic of Social Research. Belmont: Wadsworth, p. 370.

11 Susanto, E. H., \& Zhang, S. D. (2017). Op.Cit., p. 91-92.

12 Ummah, K. (2002). “Pengkanunan Hukum Islam di Indonesia dalam Hukum Keluarga," Jurnal Magister PPs UII, 5 (2): p. 97.

13 Amal, T.A., and Panggabean, S.R. (2004). Politik Syariat Islam dari Indonesia Hingga Nigeria. Jakarta: Alvabet, p. 55.

14 Nuruddin, A., and Tarigan, A.A. (2004). Hukum Perdata Islam di Indonesia, 2004, Studi Kritis Perkembangan Hukum Islam dari Fikih UU No. 1/ 1974 sampai KHI. Jakarta: Kencana, p. 9.

15 Prodjodikoro, R.W. (1974). Hukum Perkawinan di Indonesia. Bandung: Sumur, p. 25

16 First, for the Europeans, it is applied the Civil Law Act (Burgerlijk Wetboek/BW). Second, for the Chinese, it is applied Burgerlijk Wethoek, with few exceptions, namely matters relating to the recording 
The dynamics of the interfaith marriage regulation in Indonesia entered a new phase after the independence period during the Old Order with the enactment of the Law No. 22 of 1946 which consists of 7 articles, which generally contains two things. First, the necessity of the registry of marriage, divorce, and reconciliation; and secondly, the assignment of the assigned employees to registry marriage, divorce, and reconciliation. In its development, this law was expanded to the entire territory of Indonesia with Law No. 32 of 1954, namely the Law on the Registry of Marriage, Divorce and Reconciliation. However, in fact, the existence of Law No. 22 of 1946 should be valid throughout the Indonesia, but in reality, it is not yet possible, and it is only applied on the region of Java and Madura. Almost ten years after independence, the Law No. 22 of 1946 formally enacted for the entire territory of Indonesia, by becoming Law No. 32 of 1954.

The formulation and regulation of marriage entered a new phase during the New Order era with the enactment of the 1974 Marriage Law. The 1974 Marriage Law applies to all Indonesian citizens, regardless of religion. The existence of Law No. 22 of 1946 encouraged the release of Law No. 1 of 1974 which became effective since the first of October, 1975. Beside the 1974 Marriage Law, there are the Compilation of Islamic Law (hereinafter, "KHI") enacted by Presidential Instruction (Inpres) No. 1 of 1991. $\mathrm{KHI}$ is the embodiment of Islamic law which has Indonesian character. ${ }^{17}$

In KHI, the interfaith marriage is read through three things: First, the difference of religion as a lack of marital terms; Second, religious differences as the reason for the prevention of marriage; Third, the difference of religion as the reason for the cancellation of marriage. ${ }^{18}$ In addition, based on the 1974 Marriage Law, it is not explained at all. ${ }^{19}$ According to some experts and law practitioners, there are found three different understandings in the view of marriage law when associated with the interfaith marriage. First, the interfaith marriage is a violation of the 1974 Marriage Law, Article 2 paragraph (1) and Article 8 letter (f); Second, the interfaith marriage is not a violation of the 1974 Marriage Law, but it is valid and can be held because it has been covered in intermarriage. Third, the interfaith marriage is not regulated in the 1974 Marriage Law.

In principle, there are three aspects that cause the interfaith marriage is denied on de jure regulated in the Indonesian legislation. First, the political aspect. The political dynamics of interfaith marriage law become hot commodities issue, either reduced, supplemented or changed, although in the end, all the factions of people's representatives agreed. This is due to the changes and improvements to be made as

of life and the event. Third, the Arabs and the Foreign Orient who are not Chinese, their customary law is applied. Fourth, for indigenous Indonesians, it is applied their customary law, based on Stbl. No.74 of 1933. Fifth, for those who do not belong to the four groups, it is applied the intermarriage laws of Ibid, p. 14-15.

17 Bisri, C.H. (1992). "Pengembangan Wilayah Penelitian dan Pranata Sosial," Mimbar Studi, Jurnal Ilmu Agama Islam, 23(1), p. 92.

18 Karsayuda, M. (2006). Perkawinan Beda Agama: Menakar Nilai-nilai Keadilan Kompilasi Hukum Islam, Yogyakarta: Total Media, p. 138.

19 Article 2 (1) the 1974 Marriage Law, states: "Marriage is lawful, if it is done according to the law of each religion and belief." For this reason, in the explanation of the Article 2 (1) affirmed that with the formulation of Article 2 (1), there is no marriage outside the law of his religion and belief, in accordance with the 1945 Constitution. As a results, this provision describes that, for Moslems, there is no possibility to marry by violating their own religious law. Likewise, for Christians, Hindus, and Buddhists as found in Indonesia. 
law. Approval of the House of Representatives (DPR) on the enactment of the Bill on Marriage as a law is presented in its Decree Letter No. 5/DPR-RI/II/73-74.

Second, the facts of socio-cultural aspects state that, the majority of Indonesian Moslem reject the interfaith marriage. Because such marriage is considered as contradictive to the Islamic creed and law. On the contrary to Article 29 of the 1945 Constitution and Pancasila. Islamic law has become the law awareness of the majority of the society. For people who adhere to the teachings of their religion will not violate the provisions that have been established by their religion.

Third, religious theology. From the official religion recognized by the state, such as Islam, Christianity, Catholicism, Hinduism, Buddhism prohibits the form of interfaith marriage. From the theological aspect, the interfaith marriage is less appropriate with the marriage system based on religion. Because such marriage violates the provisions of the beliefs of each religion. Marriage in general aims to form a happy and eternal family based on the Belief in the One and Only God. This goal will be achieved if marriage is established through the inner bond. Therefore, marriage is not only as a dimension of law but also as an inner-dimensional engagement that is oriented to the value of the Deity. Therefore, marriage engagement is sacred. All religions in Indonesia do not want its adherents to marry different religions people. Likewise, the majority of society who hold strongly on their religious beliefs, do not justify the interfaith marriage.

Legislation is considered in accordance with the sociological foundation if its provisions are in accordance with the belief or law consciousness of the society. The majority of Indonesian people embraces the official religion legitimated by the state. All religions adherents do not justify and do not want the existence of interfaith marriage, therefore it is appropriate if the basis of marriage is based on religious law. The legitimate of marriage based on the religion in accordance with the law philosophy of Pancasila, the first principle of Belief in the One and Only God. Thus the interfaith marriage which views marriage as a civic engagement only is incompatible with the law philosophy of Pancasila and the philosophy of religions.

\section{Marriage Values in Inter-Religious Perspective}

The majority of religious law views marriage as a sacred act, which is a commitment between a man and a woman in fulfilling the command of God Almighty. So that family life, marriage and community altogether run well according to the teachings of their respective religions. This means that marriage is a physical and spiritual engagement which brings legal consequences to the religion of both brides and their families and societies. Therefore, every religion does not justify interfaith marriages. ${ }^{20}$ The interfaith marriage is incompatible with the philosophy of marriage purpose in Indonesia because the purpose of marriage is to establish an eternal and happy family based on the One and Only God. This means that the eternal and happy family should be under the auspices of Deity (religion) and not contrary to each respective religion.

Marriage in the Islamic context is not only an engagement between two different genders of individuals who have civil relationships only, but marriage also means worshipping. ${ }^{21}$ It brings wider consequences, meaning that marital legitimation is not

20 Hadikusuma, H. (2007). Hukum Perkawinan di Indonesia Menurut Perundangan Hukum Adat dan Hukum Agama. Bandung: Mandar Maju, p. 10.

$21 \quad$ Ibid., page., 244-246 
only measured on a mere formal condition, but religious value also becomes substantial. ${ }^{22}$ In the 1974 Marriage Law, each religion and belief become the benchmark of marriage, as well as in the marriage of KHI which is the form of adherence to Allah and the worship implementation towards Him. ${ }^{23}$ Religion and belief respectively, become the substance of marriage due to the achievement of marriage goals of which depends on these factors. ${ }^{24}$

The interfaith marriage is not in line with the religious sense of society justice. This is evidenced by the emergence of various reactions, especially from the couples' close family. Empirically, it also shows that religious differences are the greatest potential for the household's disharmony, so the goal of fostering a happy household will not be achieved. It must be admitted that there are few religious couples who can maintain their marriage bonds. Therefore, the few ones cannot be used as a benchmark in determining the law that meets the sense of justice. Because when value differences occur, then the greater importance should be prioritized. ${ }^{25}$

In Catholic, the interfaith marriage is not the ideal form of marriage and it is difficult to realize the purpose of marriage itself. Strictly in the Canon: 1086 declares marriage between Catholics and non-Catholics is illegal. Protestantism is looser than Catholicism in matters of religious marriage. Protestants want their adherents to marry the same religious adherents, because the goal of marriage is to reach the happiness of the household which will be difficult to reach if there are differences in beliefs.

By comparison, in Buddhism, although giving freedom to its adherents in choosing a spouse, but one of the conditions that must be fulfilled in marriage is that the candidate must have the same religion as them (one dharma) and done based on the Buddhist ordinances. Hinduism determines whether a marriage is legitimate or not based on the religion. Thus, marriage must be done according to Hindu law and for the legitimation, it must be based on the Hindu marriage by Priest or Pinandita. The interfaith marriage is not declared as valid by Hindu, except the non-Hindus are sacred through a religious ceremony that they officially become a Hindu. Marriage in Hinduism is a way for fostering households which aims to form a happy family (grahasta asrama) based on the Belief in the One and Only God. Confucius considers marriage as a sacred thing, but the religious differences of each couple are not a problem. Marriage is not determined by religion, but the determinant is that there is no coercion, approved by both brides, getting the blessings of both parents and being confirmed in religious events. Family harmony is determined by the virtues of each partner.

Finally, every religion views marriage as an engagement and a covenant between individuals of the opposite gender which aims to form a happy, eternal family based on the Religious values. Although marriages are loaded with religious values, yet every religion is different in managing them, because each religion has different scriptural guidelines. On the other hand, marriage is also regarded as a legal act, because marriage is about life that related to the relationships between individuals and society.

22 Article 2(1) of the 1974 Marriage Law, , a marriage is lawful, if it is done according to the law of the respective religion and faith.

23 The Compilation of Islamic Law, Inpres No.1 of 1991 Article 2.

24 Ghozali, A.R. (2003). Fikih Munakahat. Jakarta: Kencana Prenada Media Group, p. 24.

25 Anshori, A.G. Op.Cit., p. 220. 


\section{Legal Policy of Interfaith Marriage in Indonesia}

Indonesian people have a distinctive characteristic of diversity. This diversity often affects the practice of marriage in society, such as interfaith marriage. Interfaith marriages have been occurred since the colonial era. The release of the 1974 Marriage Law is a form of unification of marriage law. According to some opinions, it is not really able to answer thoroughly the marriage problems, especially interfaith marriage. Even, based on the release of the law, it further complicates the matters of interfaith marriage, because this regulation does not include explicitly about the interfaith marriage. The unclearness of marriage law regulation in dealing with the interfaith marriage is considered to be the same as forbidding the interfaith marriage. Therefore, the couples who have unstoppable love, find a way to implement their marriage.

There are three ways in implementing the interfaith marriage in the society: First, asking for the court decision. On the basis of determination of the court, the couple married in the Civil Registry Office. However, since the release of Presidential Decree no. 12 of 1983, such marriage way in Civil Registry cannot be done anymore. Second, marriage is done according to the law of each religion that is by doing two marriages, the first marriage is done according to the religion of the prospective husband, then after completing the first one, it continues to the second marriage which is according to the religion of the prospective wife. Or by way of legal subjection that is, one of the couple converted either follow the religion of the husband or the wife based on the agreement. Third, marriage is done overseas. An abroad marriage in one year of driving may be registered at the Civil Registry. ${ }^{26}$

In conclusion, it shows that the interfaith marriage in the society is based on the civil records, religious authorities, and marriage records abroad. There are several reasons stated, for example, marriage is held in the Civil Registry Office because each of the prospective couples want their marriage done by maintaining their respective religions, or each of their parents prohibit the marriage to be done in one party's religion. Interfaith marriage which carried out on the basis of religious authority, states that they have a reason to assume God is unlikely to punish his adherent which have good will and good deeds. As for women following the husband's religion because in the law, women should follow the husband, or for men who follows the wife's religion with a practical reason so that their marriage approved by his in-laws. While the basic reason often expressed by different religious couples who marry abroad, is that they want the marriage to be continued by maintaining each respective religion. ${ }^{27}$

26 Darmabrata, W. (2003). Tinjauan Undang-Undang Nomor 1 Tahun 1974 tentang Perkawinan Beserta Undang-Undang dan Peraturan Pelaksanaanya, Jakarta: Gitama Jaya, p. 102

27 The main reason that was stated by the couples who enreact interfaith marriages in the country with the determination of courts and institutions that are authorized, as well as those held abroad is to maintain their own religion. For example, the marriage of Andi Vonny (Islam) with Andrianus Petrus Hendrik Nelwan (Protestant) with the determination of the Supreme Court's Jurisprudence Reg. 1400/K/Pdt/1986. The marriage of Lydia Kandau (Protestant) with Jamal Mirdad (Islam) with the determination of South Jakarta District Court No. 238/Pdt/P/1989/PN. Jakarta Selatan, May 2, 1989. Marriage Roy Chandra Lesmana (Islam) with Rina Ayuningsih (Kristen) with the determination of Districti Court of Semarang No. 21/Pdt/P/2001/PN. Semarang. Similarly, Marriage Sri Martani (Catholic) with Suryo Hadiwidjoyo (Islam) with the determination of District Court of Semarang No. 112/Pdt.P/2008/PN.Ska. and the marriage of Hangga Pratama Wardono (Kristen) with Asih Kurniati (Islam) with the determination of District Court of Surakarta No. 69/Pdt.P/2011/PN. Ska. 
Interfaith marriage cases in the society in the form of submission to one spouse either to the religion of husband or wife in practice is in accordance with the religion of his choice. Therefore, the form of marriage in the form of submission is not categorized as an interfaith marriage, but belong to the one-religion marriage and legal status is according to the religion to which the subjugation is done. While the different religious couple who maintain their respective religions, the courts will give the determination in this case, sometimes it has different decisions between courts. ${ }^{28}$

Before applying the permit determination to the court, different religious couple, should apply for the will of marriage to the Office of Population and Civil Registry first. The Office of Population and Civil Registration on the application conducts an examination and refuses to carry out the registration of marriage, on the grounds of the existence of religious differences. This religious difference is deemed not to meet the provisions of Article 2 clause (1) of the 1974 Marriage Law. On the basis of the rejection from the Civil Registry Office, the prospective bride continue filing a petition to the local District Court (PN). ${ }^{29}$

The court refused to give permission to the couple of different religions, because the consideration basis on judge opinion perception is that the 1974 Marriage Law does not regulate the interfaith marriage. While what is regulated and registered according to the law is the same religious couple, namely in the Office of Religious Affairs for the Moslem and the Office of Civil Registry for non-Muslims. ${ }^{30}$ Article 2 (1) of the 1974 Marriage Law, "Marriage is lawful, if it is done according to the law of their respective religion and belief". This article indicates the prohibition of interfaith. Likewise, Article 8 (f) states, "a marriage is prohibited if it has a relationship which by its religion and other applicable regulations, is prohibited to marry each other". 31 In religions that exist in Indonesia, none of them wants and allows the interfaith marriage. But in Christianity, Catholicism, Hinduism, Buddhism there is dispensation, which is the permissibility of a couple of different religions to marry on the condition that must be done through a religious way of giving dispensation. This marriage is equal to the same religious marriage.

28 The difference of judges' determination in rejecting or granting interfaith marriages is often influenced by the understanding of Article 2 concerning the legacy of marriage, Article 8 concerning the prohibition of marriage, Article 57 on Intermarriage and Article 66 on the enactment and absence of marriage rules in the 1974 Marriage Law.

29 Article 21 of the 1974 Marriage Law: (1) if the marriage registry official believes that the marriage is prohibited under this law, he will refuse to marry. (2) in the case of rejection, the request of any party wishing to marry by an employee of a marriage certificate shall be given a written statement of the denial accompanied by the reasons for its rejection. (3) Parties whose marriage is denied are entitled to apply to a court within the territory in which the marriage recipients of the residence have a residence to make a decision, by submitting the letter of rejection mentioned above. (4) The court will review the case with a brief event and will provide a stipulation whether or not to reinforce the refusal or to order the marriage to take place.

30 Government Regulation No. 9 of 1975 Article 2 clause (1) jo. Article 20 of the 1974 Marriage Law.

31 The Rejection Case of interfaith marriage by the Jakarta District Court was carried out by Andi Vonny (Islam) with Andrianus Petrus Hendrik Nelwan (Protestant) in 1986, because the local KUA rejected the petition for marriage parties because the couple have different religions. so does KCS do the same as what KUA does. 
The existence of choice of law to determine the religious law used in implementing the marriage shows that the husband and wife have the same position..$^{32}$ It is in accordance with the human rights values and the freedom to choose religion as proposed in Article 29 of the 1945 Constitution as the highest law. The choice of law will provide legal certainty for different religious partners or their interest will be protected. ${ }^{33}$

The Court which grants the decision of the interfaith marriage is based on that the 1974 Marriage Law does not regulate the interfaith and does not contain any provision stating that interfaith marriage is prohibited or as a marriage barrier. ${ }^{34}$ Article 35 letter (a) of Law No. 23 of 2006 on the Population Law shows that interfaith marriage can be registered at the KCS. ${ }^{35}$ Similarly, in Article 10 (3) of Government Regulation No. 9 of 1975, Article 28 B of the second amendment and Article 29 of the 1945 Constitution of the Republic of Indonesia shows that religious differences do not become a barrier for the marriage, because in principle, a marriage is a way to form a harmonious, eternal, loving, caring and respectful household.

Decision of the Supreme Court on the interfaith marriage, stated in the Decision of the Supreme Court Jurisprudence Registration No. 1400/K/Pdt/1986 which grants the interfaith marriage. The reason for this consideration is that in this case a Moslem applicant have applied for a marriage with a Protestant Christian man to KCS in Jakarta, it must be interpreted that the applicant intends to marry not in Islamic way, and must also be interpreted that the applicant has ignored the religion status (Islam).

Responding to this matter, if it refers to Article 66 of the the 1974 Marriage Law which states that for marriage and all things related to marriage based on this law, then with the enactment of this law, the provisions set forth in the Book of Civil Law (Burgerlijk Wetboek), Marriage Ordinant of Indonesian Christian (Huwelijk Ordonantie Christen Indonesiers S. 1933 No. 74), Intermarriage Regulation (Regeling op de Gemengde Huwelijken S. 1898 No. 158) and other regulations governing marriage to the extent provided for in this law shall be invalid. This article also provides an opportunity for the interfaith marriage to be carried out using marriage laws that are in force before the 1974 Marriage Law. The law clearly does not regulate the interfaith marriage, it can use

32 General Explanation of the 1974 Marriage Law letter (f) indicates the right and status of the wife is equal to the rights and position of the husband, both in domestic life and in the society, so that everything in the family can be negotiated and decided jointly by husband and wife.

33 The essence of the existence of the law is actually the protection of human interests.

34 The prohibition of marriage in the 1974 Marriage Law as described in Article 8, Article 9, Article 10 and Article 11. While interfaith marriage is not included in the reference of prohibition of marriage. The prohibition of marriage in Article 8, among others are a. having related-blood both straight down or upward; b. Having related blood in the lateral lineage, ie between siblings, between a person with a parent's brother and between a person and his grandparents; c. Having related because of marriage, namely in-laws, stepchildren, in-laws and mother/stepfather; d. Having same breast-feeder, namely the parents of breast-feeder, child of breast-feeding, relatives and aunt / uncle of breast-feeder; relating you to a wife or as an aunt or nephew of a wife, in the case of a husband having more than one wife; $f$. Having a relationship which by his religion or other applicable regulations is prohibited from marrying. Article 9, a person who is still married to another person shall be unable to remarry, except in the case referred to in Article 3 (2) and Article 4 of this law. Article 10, if a divorced husband and wife marry again, one with another and divorce again for the second time, then there shall be no further marriage, as long as the law of their respective religion and belief from that of another does not determine otherwise. Article 11, (1) for a woman whose marriage is terminated shall be a waiting period; (2) the period of waiting period referred to paragraph (1) shall be regulated in a further Government Regulation.

35 The marriage registration in Article 34 shall also apply to a marriage which is reenacted by the Court. While in the article, the explanation of letter a means "marriage established by the Court" is an interfaith marriage. 
the Intermarriage Regulation (Regeling op de Gemengde Huwelijken S. 1898 No. 158) which explicitly regulates it.

However, the Supreme Court in its decision did not use the reasons of Article 66 of the 1974 Marriage Law as noted above. Because the Supreme Court considers there is a fundamental philosophical difference between the two marriage rules. In the 1974 Marriage Law states marriage is considered legal if it is done according to the law of each religion and belief. This means marriage is regarded not only as a merely administrative engagement, but also contains elements of divine values, in accordance with the philosophy of the Pancasila state that is based on the Belief on One and Only God. ${ }^{36}$ While GHR as a legal product of the West Law considers marriage is seen only as a bond and a civil relationship. Furthermore, the Supreme Court Decree considers the case of interfaith marriage has a legal vacuum and this cannot be justified ongoing because the community in fact needs it. Therefore, the interfaith marriages is done by the parties who have ignored their religion. Thus, the authority who hold or assist the execution of such marriages is KCS.

In this case, even if an act is not regulated in law, but contrary to public order and justice, then it is prohibited. While acts which are not regulated in the law, but are needed for justice, benefit and legal certainty, then the act is allowed. The legal vacuum must be filled, completed and this is the duty of the judge. In this context the judge has full authority in determining and interpreting the law or conducting legal discovery. ${ }^{37}$

Likewise, in the next case, the perpetrator of an interfaith marriage is not only through the judge's appointment to be able to keep his marriage will, but also to marry abroad. Under the provisions of Article 56 (1) of the 1974 Marriage Law Marriage, which held outside Indonesia between two Indonesian citizens or an Indonesian citizen with a foreign citizen is lawful if it is done under the law applicable in the country where the marriage is held and for Indonesian citizens do not violate the provisions of this law. This provisions indicate that marriages abroad are only administrative arrangements or regulate the registration of marriage, divorce, reconciliation, not legal documents. Therefore, the interfaith marriage abroad conducted by Indonesians is an act of law smuggling, both partners try to avoid the law or the implementation of national law. ${ }^{38}$ Despite the interfaith marriage abroad as legal smuggling, the marriage is still

36 National laws and all state legislation products must be based on Pancasila as an ideology that became the basis for a system, as well as a life goal Indonesian. First principle of Pancasila and the 1945 Constitution Article 29 (1) based on belief in one supreme God. Belief in One and Only God as the basic spirit of law in Indonesia showed that the 1974 Marriage Law is very appropriate if it is based on religion. According to Azhari, the State based on the Belief in One and Only God contains 3 (three) meanings; first, the state may not enact legislation or implement policies contrary to the basis of faith in God Almighty; second, the state is obliged to enact legislation or conduct policies for the execution of a sense of faith to God Almighty of a group of believers who need it; third, the state is obliged to make laws and regulations that prohibit anyone from harassing religious teachings. See: Azhari, M.T. (1997). Menegakkan Syari'at Islam dalam Konteks Keindonesiaan: Proses Penerapan Nilai-Nilai Islam dalam Aspek Hukum, Politik dan Lembaga Negara. Bandung: Mizan, p. 28

37 In attempt to discover the law through either grammatical, systematic or logical, teleological, sociological, and historical interpretation of the source of the law. The main sources of legal discovery are legislation, customary law, jurisprudence, international treaties and doctrines. Mertokusumo, S. (2010). Penemuan Hukum. Yogyakarta: Atmajaya University, pp. 62-80

38 The smuggling of laws in Dutch is known as "Wetsontduiking", in French as "Fraunde a la loi", in Latin as "Fraus legis", in English as "Fraudeulent creation of point of contacts", and in Italian as "Frode alla legge". The aim of legal smuggling is to be able to avoid an undesirable legal effect or to bring about a due legal effect. Therefore, there is always the element of subjectivity that is in the form of will or intention to smuggle something. See: Gautama, S. (1981). Hukum Perdata International Indonesia. Bandung: Alumni, pp. 221-222. 
considered valid. Article 83-84 of the Civil Code KUH, explains that marriages held outside Indonesia, whether between Indonesian citizens and other citizens are valid, if marriage takes place in the manner or rules of the country and does not violate the provisions of the Civil Code KUH. Then within a year after the husband's wife returns, the marriage must be registered in the register of marriage in their residence.

The provisions of Article 56 in the 1974 Marriage Law as well as Article 83-84 of the Indonesian Civil Code, states that marriage legitimation conducted abroad depend on the fulfillment of formal conditions and material requirements. As the formal requirements, the marriage must be done according to the applicable law where the marriage is held. While the material requirements is to not violate the provisions of this law. If so, the marriage may be legitimately formal, but not materially legal. The marital innocence due to a material condition is violated, consequently the marriage may be canceled.

During this period, marriage abroad is still considered lawful. The deed they have obtained abroad is universal. Then, upon arrival in Indonesia the registration of marriage abroad to the Department of Population and Civil Registry is only considered as the fulfillment of mere population administration. It is including the reports of all the events of residence and other important events. The report registration is not related to the legitimacy of marriage legitimacy, the registrar officer only view that they already have a marriage certificate obtained from the country where the marriage is held. ${ }^{39}$

The interfaith marriage conducted by the society within the unitary state of the Republic of Indonesia both with the system of court and marriage abroad, its validity is only administrative. Whereas the nature of the legitimacy of a marriage legal law rests on the validity of the religion, as described in Article 2 (1) of the 1974 Marriage Law. Administrative validity is accommodated by Article 2 (2) the 1974 Marriage Law. A marriage which emphasizes on administrative legitimacy only is the same as civil marriage, as Western nations do. 40 But it cannot be denied because of the influence of society's diversity and modernity, so that the barriers in society are opened, which then allows the interfaith marriage in the society.

In a religious society such as Indonesia for example, undesirable influence of western modernity and culture fills the submission of religious adherents to their religion. On the other hand, the hoarse of western culture and modernity that is identical with

39 In the Law No. 23 of 2006, applies some provisions on interfaith marriage. The interfaith marriage which is conducted abroad shall be registered with the competent authorities of the country and reported to the representatives of the Republic of Indonesia. If the country does not recognize the registration of foreigners, then the registration shall be done by the representative of the Republic of Indonesia by being registered in the Marriage Deed Register, then disciplined by the Marriage Deed. If the couple returns to Indonesia, the married couple must report to the Department of Population and Civil Registration no later than 30 days after arrival in Indonesia. If it is not done the couple is threatened with administrative fines, as in Presidential Regulation No. 25 of 2008 that the authority of administrative fines shall be regulated by the Regional Government. With the provisions of Law No. 23 of 2006 and Government Regulation No. 37 of 2007 as a Regulation of the Implementation and reinforced by Presidential Regulation No. 25 of 2008. As a result, Indonesian citizens who held interfaith marriages abroad more and more for some reason. See: Suganda, D. (2005). Pernikahan WNI di Luar Negeri dan Pola Pencatatannya. Jakarta: The Prosecutor of Dawn, p. 5

40 Law products that have been applied in Indonesia such as, GHR, BW and HOCI and other Western legislation in the field of marriage are evidence of the applicability of civil law. Because philosophically and sociologically the legislation is not compatible with the Indonesian state based on Pancasila and the majority of its population who are religious. 
liberalization tends to affect the looser and permissive patterns of thought and behavior to deviations of religious laws. Therefore, there should be a refresher of understanding in the society that the marriage is not only an engagement between two different genders of individuals to foster a household that is only outwardly, but also in the spirit of the 1974 Marriage Law.

The legal policy of interfaith marriage in the future still refers to one of the ideals of Pancasila's principle. Beside containing the critical aspects with the ideals of law as a critical norm for the implementation of the law, it is also in accordance with its objective of creating order and justice in accordance with the social context of society religious-communal society. The regulation adopts a law lives in society and does not conflict with the ideals of Pancasila, whether from customary law, Western law or Islamic law.

There are four rules that should be guidelines for the national legal system based on Pancasila: Firstly, national law must be able to maintain the integrity of both ideology and territory in accordance with the purpose of protecting the entire nation and the whole of Indonesia. Legal products that potentially divide the integrity of the nation and state including primordial discriminatory laws should be avoided and prevented. Secondly, the law must be built democratically in the sense that it should contain participation and absorb the aspirations of the wider society through fair and transparent and accountable procedures and mechanisms. Third, the law is aimed at creating social justice in the sense of being able to provide special protection against the weak. Four, the law must guarantee religious freedom with tolerance among its adherents and there should be no privilege of inter-religious treatment amongst the other. States may regulate religious life to the extent of maintaining order to avoid conflicts and facilitate that everyone can implement his religious teachings freely without disturbing others. ${ }^{41}$

The regulation of marriage in Indonesia embraces the legal system of Pancasila in which the first principle which is "Belief in the One and Only God" inspects the legitimacy of a marriage. The 1974 Marriage Law affirms the concept of marriage adopted based on the principle of Belief in the One and Only God does not allow the existence of a secular marriage. This further reinforces that every marriage legal regulation in the form of marriage law always involves religious elements. Religious values will be given a sociological and ideological meaning, both substantial and functional. With functional meaning, religion becomes an interpretive media that will help humans to unlock the mystery of the veil and the universe. In substantial meaning, religion becomes a media related to supra natural or transcendent world.

\section{Conclusion}

The interfaith marriage is not regulated in the 1974 Marriage Law, because: First, the rejection of the majority of Muslims and the faction in Parliament because the interfaith marriage is against the aqidah (matters of faith) of Islam; Second, the interfaith marriage is contrary to the marriage culture in Indonesia, because marriage contains legal, sociology and religious aspects; Third, the interfaith marriage is contrary to the theological teachings of religions in Indonesia that do not want interfaith marriages, such as Islam, Christianity, Protestantism, Hinduism and Buddhism. Furthermore, the interfaith marriage is inconsistent with the philosophical purposes of marriage in

41 Mahfud, M.D. (2010). Konstitusi dan Hukum dalam Kontroversi Isu. Jakarta: Rajawali Press, pp, 38-39. 
Indonesia where the purpose of marriage forms a happy and eternal family based on the One Supreme God.

The marriage must be in accordance with Pancasila as the nation's ideology as well as the 1945 Constitution as the highest law. The legal certainty of interfaith marriage through the registration according to the 1974 Marriage Law Article 2 (2) in the Office of Civil Registry with the stipulation of the Court is in accordance with Article 35 letter (a) of the Law No. 23 of 2006 on Population Administration.

\section{References}

Amal, T.A., and Panggabean, S.R. (2004). Politik Syariat Islam dari Indonesia Hingga Nigeria. Jakarta: Alvabet.

Anshori, A.G. (2012), Antologi Hukum Islam. Yogyakarta: PPs Universitas Islam Negeri Sunan Kalijaga.

Arief, A.S. (2003). Pembaharuan Pemikiran Hukum Islam: Antara Fakta dan Realita (Kajian Pemikiran Hukum Syaikh Muhammad Syaltut). Yogyakarta: LESFI.

Azhari, M.T. (1997). Menegakkan Syari'at Islam dalam Konteks Keindonesiaan: Proses Penerapan Nilai-Nilai Islam dalam Aspek Hukum, Politik dan Lembaga Negara. Bandung: Mizan.

Bable, E. (2002). The Basic of Social Research. Belmont: Wadsworth.

Bisri, C.H. (1992). "Pengembangan Wilayah Penelitian dan Pranata Sosial," Mimbar Studi, Jurnal Ilmu Agama Islam, 23(1): 92.

Darmabrata, W. (2003). Tinjauan Undang-Undang Nomor 1 Tahun 1974 tentang Perkawinan Beserta Undang-Undang dan Peraturan Pelaksanaanya, Jakarta: Gitama Jaya.

Gautama, S. (1981). Hukum Perdata International Indonesia. Bandung: Alumni.

Ghozali, A.R. (2003). Fikih Munakahat. Jakarta: Kencana Prenada Media Group.

Hadikusuma, H. (2007). Hukum Perkawinan di Indonesia Menurut Perundangan Hukum Adat dan Hukum Agama. Bandung: Mandar Maju.

Karsayuda, M. (2006). Perkawinan Beda Agama: Menakar Nilai-nilai Keadilan Kompilasi Hukum Islam, Yogyakarta: Total Media.

Mahfud, M.D. (2010). Konstitusi dan Hukum dalam Kontroversi Isu. Jakarta: Rajawali Press.

Mertokusumo, S. (2010). Penemuan Hukum. Yogyakarta: Atmajaya University Press.

Nuruddin, A., and Tarigan, A.A. (2004). Hukum Perdata Islam di Indonesia, 2004, Studi Kritis Perkembangan Hukum Islam dari Fikih UU No. 1/ 1974 sampai KHI. Jakarta: Kencana.

Prodjodikoro, R.W. (1974). Hukum Perkawinan di Indonesia. Bandung: Sumur.

Suganda, D. (2005). Pernikahan WNI di Luar Negeri dan Pola Pencatatannya. Jakarta: The Prosecutor of Dawn.

Susanto, E. H., \& Zhang, S. D. (2017). Critical Discourse Analysis of Interfaith Marriage News from Cyber Media in Indonesia. Journal of Educational and Social Research, 7(1), 91.

Ummah, K. (2002). "Pengkanunan Hukum Islam di Indonesia dalam Hukum Keluarga," Jurnal Magister PPs UII, 5 (2): 97. 